\title{
Contextual determinants of decentralization of epidemiological surveillance for the family health team
}

\author{
Silvone Santa Barbara da Silva Santos ${ }^{(a)}$ \\ Cristina Maria Meira de Melo(b) \\ Clemence Dallaire ${ }^{(c)}$ \\ Michel Perreault ${ }^{(\mathrm{d})}$ \\ Edna Maria Araujo(e) \\ Evanilda Souza de Santana Carvalho ${ }^{(f)}$ \\ Luciano Marques dos Santos(g)
}

Santos SSBS, Melo CMM, Dallaire C, Perreault M, Araujo EM, Carvalho ESS, et al. Determinantes contextuais da descentralização da Vigilância Epidemiológica para Equipe de Saúde da Família. Interface (Botucatu). 2015; 19(54):443-54.

This study examines the contextual determinants of implementing decentralization of epidemiological surveillance for the family health team, in a municipality in the state of Bahia, Brazil. This was an evaluative study using the political model of implementation analysis. Data were obtained through document analysis and semi-structured interviews with managers and healthcare workers. Five themes emerged: planning; training of human resources; organization of the work process; linkage within institutions; and organization of family healthcare units. The results revealed that there are difficulties such as poor infrastructure of healthcare units, creation of flexibility in labor relations and healthcare worker turnover. The study shows that there is a need for stakeholder participation in the process of implementing the policy of decentralization of epidemiological surveillance for the micro-area of intervention that comprises the family health program.

Keywords: Epidemiological surveillance. Decentralization. Contextual determinants. Family health team.
Este estudo analisa os determinantes contextuais da implantação da descentralização da vigilância epidemiológica para a Equipe de Saúde da Família, em um município do estado da Bahia, Brasil. Trata-se de pesquisa avaliativa, adotando-se o modelo político da análise de implantação. Os dados foram obtidos mediante a análise de documentos e entrevistas semiestruturadas aplicadas a gestores e trabalhadores da saúde. Emergiram cinco temas: Planejamento; capacitação de recursos humanos; organização do processo de trabalho; articulação intrainstitucional; organização da Unidade de Saúde da Família. Os resultados revelam dificuldades tais como: precária infraestrutura das unidades de saúde, flexibilização das relações de trabalho, rotatividade dos trabalhadores da saúde. O estudo aponta para a necessidade de participação dos atores no processo de implementação da política de descentralização da vigilância epidemiológica para um micro-espaço de intervenção que é o Programa de Saúde da Família.

Palavras-chave: Vigilância epidemiológica. Descentralização. Determinantes contextuais. Equipe de Saúde da Família.

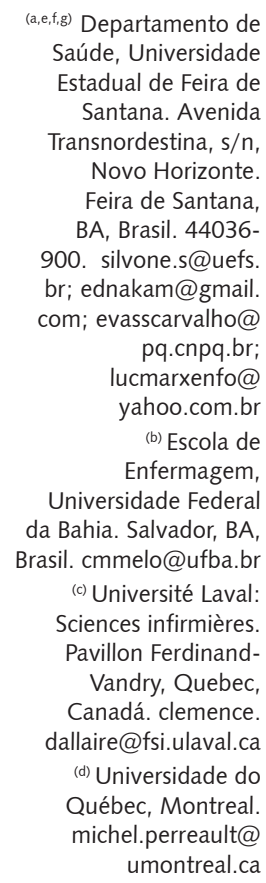
umontreal.ca 


\section{Introduction}

From the twentieth century to the beginning of this century, social policies in Brazil have undergone profound transformations. The decentralization of health, basic education, social welfare, sanitation and affordable housing was among the priorities on the agenda of Brazilian officials ${ }^{1}$ as it was the case in general in occidental societies in those years ${ }^{2}$. However, more than just an administrative process, decentralization is also a political process involving the transfer of power, in this case from federal to regional and municipal entities.

According to Guimarães ${ }^{3}$ despite the legal-normative structure negotiated and agreed upon by the social actors involved, a conflict between the three spheres of government is inherent to the decentralization in the health sector in Brazil, partly due to resource and power imbalances among the levels of government. This unequal division impedes the full implementation of the Unified Health System (UHS).

The Brazilian Constitution of 1988 established the Unified Health System with the doctrinaire principles of universality, integrality, and equity in access to health services and established as organizing principles: the decentralization of health services and programs; the regionalization and hierarchy of the health network; and social participation ${ }^{4}$. The Family Health Strategy is regarded as a structuring strategy of the Unified Health System (UHS), in that it was designed to restructure the healthcare model, originally focused on hospital and medical practice (strategy defined by Brazil's health ministry aiming at reorienting health practices, with emphasis on primary care).

Evidence suggests that the conceptual definition of decentralization implies a political dimension related to the sharing of decision-making power. As we can see, the administrative dimension often seems privileged with an emphasis on transfer of functions and responsibilities between spheres of government. In this sense, the so-called current decentralization in the health care system could be characterized more as a dispersion of activities - what is usually conceptualized as a de-concentration in the international research - than a real transfer of resources accompanied by a corresponding transfer of decision-making power ${ }^{5-7}$.

Baguenard ${ }^{5}$ mentions that de-concentration is characterized by the development of a hierarchical line of command between central government and local instances. Accordingly, Lemieux ${ }^{6}$ proposes that de-concentration or administrative decentralization is characterized by a relationship of dependency upon the local and central. Thus, in the Brazilian context, decentralization is an ideological production that is grounded in the legitimacy of power by the central federal government. This is similar to a political game which means, according to Dallaire ${ }^{8}$, the use of power to establish rules that determine which actors can participate, how they can participate, when they can engage in problem definition and goal setting, and in developing strategies such as persuasion, negotiation and sometimes direct confrontation between the interested groups. This last concept clarifies the connection between political and administrative components of the decentralization process.

The decentralization of Epidemiological Surveillance (ES) in Brazil is a priority of the federal government, as shown by the publication of basic operational standards or through financial incentives for the counties to assume an increasingly larger share of the ES. However, this is done without evaluating the capacities of the counties to develop them. Therefore, it appears that the current decentralization of ES is mainly focused on the division of actions and activities largely from a technical-administrative perspective rather than a political one $e^{3,5,6}$.

On the other hand, though riddled with contradictions, the decentralization of the management of ES expands the responsibility of mayors and municipal secretaries of health for sanitation, favors the diffusion of ES actions to the local system, enables the emergence of new demands, and increases the capacity for interventions to reduce the health problems of the population.

Although the ministerial edict on epidemiology and disease control n. 1.399, 15/12/1999 regulates the powers among the Union, the states, the counties, and the Federal District, and defines the parameters of budgeting ${ }^{9}$, it was not enough to ensure that surveillance at a municipal level would become the important link in the monitoring and evaluation of the health status of the population as it had been intended. This is because the Ministerial edict presents a vertical decentralization of ES, 
and does not allow its integration into the priorities of many local governments. This takes place in a context where the actions of ES are still focused on disease control informed by a prevailing welfare model focused on curing diseases and the corresponding hegemonic importance attributed to the hospital. Moreover, a shift in this context faces many obstacles ${ }^{10,11}$.

The changes required are situated in the administrative and political spheres, including what regards professional practices, particularly the behavior of workers ${ }^{12}$. Thus, the ES is operated in an ad hoc and fragmented way, focusing on the individual, prioritizing actions against the signals and symptoms of diseases currently prevalent according to the epidemiological data ${ }^{10,11}$.

For Baguenard ${ }^{5}$, decentralization in this case is ambiguous since the central government reduces the autonomy of the local instances by determining their activities. Meanwhile, the central government takes advantage of the apparent sharing of power to reinforce its own legitimacy. This can be observed in Brazil by the fact that although the Law of Health has democratic content and aims towards decentralization, it is not enough to ensure that the sharing of power and democracy remains an ideological legitimization of de-concentration. Yet on the other hand, even filled with its current contradictions, the decentralization of ES has many advantages since it may give more responsibility for health to mayors and municipal secretaries of Health, promote the increase of ES activities of the local system where it is most effective, and allow the emergence of new demands and extend the capability of intervention on local problems.

Watts ${ }^{13}$, comparing the decentralization of various countries (including the United States, Australia, Germany, and Canada), concluded, measuring the level of decentralization, that some countries tend to decentralize a sector - for example, the economy - to the detriment of another sector-like the legislative sector. However, Watts ${ }^{13}$ asserts that this is an essentially pragmatic form of government, evolving and not static, and it is necessary to adapt to new circumstances and needs, including learning from the example of other federations. That said, it should not only be considered whether it is good or bad to decentralize management, but rather to assess in what context decentralization occurs and what is the position of the actors who control the power base.

This article aims to examine concretely the contextual determinants of decentralization of Epidemiological Surveillance for the Brazilian Family Health Team (FHT). This current single case study ${ }^{14}$ is centered on a county in the state of Bahia, Brazil, but it is a component of a larger evaluative study entitled "Evaluation of the Epidemiological Surveillance decentralization for the Family Health Team"10.

\section{Methodology}

The implementation analysis has as its central focus the study of matter determinants and their influence in the implementation of services, programs, actions, among others ${ }^{15,16}$. The analysis of the degree of implementation of ES is based on three pillars: analysis of the influence of contextual determinants, influence of variations of the effectiveness of the ES, and the relationship between the implementation deployment context and the observed effects of ES.

To perform the implementation analysis, defining the influence of the context, we opted for the political model of evaluation. This choice is supported by the factors used by the political model to evaluate an intervention: intervention support given to their staff; if these agents are able to effectively operationalize the intervention; if there is consistency between the objectives and the support that is given to the intervention ${ }^{15,16}$, which implies analyzing a series of decisions or non-decisions that can generate action or inaction of the various actors inserted in the social context. Implementation analysis also takes into consideration the cyclical factors that influence the results obtained after the implementation of an intervention ${ }^{15}$. Consequently, to evaluate the implementation of the decentralization of ES for the FHT, it is necessary to understand the context in which this process occurs since implementation of decentralization is closely related to the organizational structure of the county.

The primary data was obtained through semi-structured interviews with managers and employees of the Municipal Health department. Secondary data consisted of the analysis of the Municipal health plan, epidemiological reports and annual report of the county. 
The participants in the survey were implemented and distributed according to the following groups: Group $1(n=4)$ : Workers in the Family Health Team (doctor, nurse, nursing assistant and a community health agent); Group $2(n=5)$ : Managers of the Municipal Health Department, Chief of ES, Chief of the Division of Primary Care, the program coordinators for the control of leprosy and tuberculosis. The sample was intentional due to the object of study.

The first motion analysis was performed based on data extracted from interviews, linking them with the original context. Thus, based on Melo ${ }^{17}$, findings were processed as follows: A general and exhaustive reading of the material collected in interviews and pre-defined categories; processing findings relating to the units of analysis and the thematic units (central theme); evaluative discourse analysis, which identifies the value judgments of the actors in relation to the implementation of the decentralization of ES for the FHS. At this stage, discourse was classified as positive or negative in relation to the decentralization process.

Secondly, after review and analysis of documents, a few variables were highlighted as related to the organizational structure and management: training of human resources priority guidelines established in the health plan, and degree of implementation of the decentralization of ES under the management reports. We developed a matrix, containing the following information: type of document; year; institutional actor; central theme and how the document was written. It was highlighted for analysis, only documents that made reference to decentralization and the central themes of the study. A relationship was established between the material collected in interviews and documents, identifying divergences and convergences listed by the actors involved in this research.

\section{Results}

Through the responses of the interviewees, it was possible to identify the following thematic units as contextual determinants in the process of implementation of decentralization for the Family Health Team: planning, training the Family Health Team, organizing the work process, intra institutional communication, and finally, the organization of the Family Health unit.

\section{Planning}

The idea of planning emerges from managers only under a centralized and punctual concept. Health workers do not report any participation in the planning process, which might indicate that the action done does not necessarily correspond to the planned action. It is clearly visible that there is a paradox among the interviewees' responses when they simultaneously reinforce the planning centralization and defend the ES decentralization.

Such a paradox may indicate that the current scenario is not yet favorable to initiating processes of change in the way of thinking and carrying out ES in the county. According to the senior manager, It is understandable we may not achieve equity, once planning is made in 'superior hierarchic levels' or 'in upper position level', not taking into consideration the specificity of each territory and the needs of each area involved.

In fact, the responses of another manager point to the implementation of decentralization without any prior planning. It is as if the actions were passed out to the FHT, aiming at solving punctual and urgent problems and intending to avoid the occurrence of epidemics. Manager B claims that the implementation of ES decentralization to the FHT had been initiated after the arising and great frequency of some diseases: "So this (referring to the actions of ES) was well centered. Then, as the diseases were occurring more frequently at the time of dengue fever, cholera cases, for example [...]".

It is interesting to note that in the first health plan, the planning of health surveillance is referred to as "It is incipient, not hierarchical and inconsistent features in their regionalization". In the second stage, when establishing it as a priority and proposing guidelines for the adoption of planning and the functional organization of the system, the health plan states that: 
In this case, the decision to plan within a strategic vision means the recognition of the need to not only seek more rational management of resources and implementation of health actions, but also the existence of diverse and conflicting political projects and space required for discussion of the formation of social agreements, temporary and effective, enabling the implementation of the policies of the sector. ${ }^{18}$ (p. 16)

Therefore, the adoption of planning as a strategic perspective is defined as a political policy, although the responses do not reflect such intention. Possibly, it refers to a political guideline from the Municipal Health department which is not inserted in the subjects' representations from this survey, and consequently, in the health practice routine.

\section{Training health workers}

Most subjects interviewed converge in their responses when they refer to training processes developed for the Family Health Team, which are considered punctual, prescriptive and concentrated only on knowledge transmission, thereby emphasizing the content on communicable diseases.

"Sometimes we participate in some... trainings, that the personal sector there (referring to the Division of Professional ES) does". (Worker health university level)

Confirming the previous assertion, by analyzing documents (Municipal Health Plan and Management Reports), it was discovered that the training was focused on decentralizing actions of specific diseases, e.g. tuberculosis, dengue, leprosy. The training possibly allows workers to learn about the epidemiology, clinical issues and control measures of the health problems. However, they are not sufficient for the changes in the practice of ES towards the paradigm where the promotion of health involves the prevention of diseases.

It is important to mention that the secondary level working class did not cite training at any moment during the interview. This possibly means that they were trained, but do not relate this training to their insertion in the ES.

\section{Organization of the work process in health}

At the Health Unit where the study was carried out, it was evident that only the Community Health Agents count on effective hiring, the others are contractors from cooperatives. One of the workers interviewed had been working at the Unit for less than two months.

"Although I have been working here for a short time, less than two months, I think the Unit is extremely organized; the health agents are very cooperative. So, I have not had any difficulty". (upper level worker)

This worker's comments reveal that the health worker does not perceive turnover as a problem for himself or for the service. This response indicates that their concern is having no difficulties in their work process, instead of how such turnover may reflect negatively on the population's access to the service.

The counties now have an open field to effect the hiring of personnel without contests. This greatly facilitates the adoption of a clientlist policy toward hiring staff often not by technical criteria, but by political election criteria. This has negative repercussions on the ES practice at municipal level, as suggested by one of the managers.

"Concerning the change at the FHT, it is turnover itself: doctors, nurses who were trained in the programs for tuberculosis, leprosy, exanthematics and others take away the knowledge 
when they leave, while those coming in, theoretically, do not have such knowledge. Therefore, there is always an interruption of this process, of the routine, of everything as it should be, as it should work".

This comment reflects the harmful consequences for the process of decentralization, when he confirms that it is always beginning. Besides that, it is affirmed there is investment in training professionals who leave the municipal district in most times.

The high percentage of nurses as managers of the health services in the referred district deserves attention, since four out of five managers interviewed were nurses, i.e. eighty per cent of the managers interviewed. It is also the nurse who takes over the management of the Family Health Unit, though they are not considered as so by the Municipal Health department.

Nursing organization in Brazil, which is influenced by the American model, probably contributes for the nurses' accumulated knowledge in this field, since the National Department for Public Health, through Rockefeller Foundation, brought American nurses to install and run the first nursing school in Brazil ${ }^{19}$. On the other hand, according to Gagnon and Dallaire ${ }^{20}$, North American nurses entered the public health movement in the 19th century, worked with hygiene, sanitary conditions and vaccination, women and children care, educational and informative campaigns, which led to specific contribution of knowledge on public health.

\section{Intra institutional communication}

One of the managers emphasized the ease of communication between the division of ES with the Strategy of Familiar Health (SFH).

"When one starts thinking of one's [...], own team, the colleague, the nurse who's there at the health unit, the doctor, we often find that communication facilities ... the FHT, they know the ES (referring to the division of the ES central part of MHS - Municipal Health System), they seek ES when they encounter problems, they are supported in ES. So I see this way as easy as we have this two-way communication, right ... then the surveillance is present and the FHT today already know how to do surveillance".

In contrast, the health professional reported that a lack of coordination between the division of ES and FHT constitutes a difficulty in performing their actions in the area covered by the Family Health Unit.

"[...] Is a great difficulty (communication) to coordinate with the other coordinator, when we think so: coordination of family health for me is a big obstacle, [because of] the person, the coordinator [...]".

The health professional's responses reveal that a lack of communication between the division of ES and the FHT constitutes an obstacle when carrying out actions inside the scope of the Family Health Unit. The absence of intra sector communication implies difficulties for implementing the decentralization of ES to the $\mathrm{FHT}$, as it impedes sharing information and decisions which would surely favor the development of more resolving actions.

What is identified as dislocation may be attributed, partly, to history due to the way the work process of ES in the municipal district was organized. This work has always been centered in trained teams exclusively for the development of surveillance actions, delegating to the Basic Health Unit workers the activity of compulsory notification of diseases.

The Ministry of Health, on the other hand, establishes that as part of the Family Health Team's duties: to know the reality of families under their responsibility, emphasizing their social, demographic and epidemiological characteristics; to identify prevailing health problems and risky situations to which 
the population is exposed; to carry out basic epidemiological surveillance and sanitary actions in its coverage areas, based on their professional qualification ${ }^{18}$.

What concerns ES, it is not only about attributing one more function, but taking over the sanitary responsibility in the coverage area, performing interventions both directly and indirectly through intersectoral communication. It is understood that health problems within the coverage area shall be treated according to complexity and resource availability, assuring assistance integrity and improvement of health indicators.

\section{Family Health Unit Organization}

For some interviewees, team work in this field is just telling the other the occurrence of a fact, so the other decides what to do. However, team work means to work horizontally, developing integrated actions, uniting knowledge and its subjects, considering singularities of each profession practice, under the perspective of building coherent proposals and answers to the population's needs. Also, to work in a horizontal way means to build communication networks among the subjects involved, and considering and valuing the resources each subject has whether it be information, attitude, ability or competence, which opposes work logics that are essentially bureaucratic and hierarchic.

It is stressed by some of the interviewees that they develop ES actions with ease, reporting that the implantation of decentralization did not change the dynamics at the Unit. The availability of a vehicle to perform actions and the weekly schedule at the Unit, which comprises home visits fulfilled by health professionals, is cited as a facilitator. This fact allows reinforcing the idea that ES represents a secondary activity for the HFT. This representation is incorporated by a large amount of professionals for not understanding the ES as an action inserted in many other health actions.

It's been a good job with the team, we have managed a team that really understands that discuss the problems that take away the doubts, I have no complaints on our team, and our team has managed to do a reasonable job (Community Health Agent).

An ES manager commented that the decentralization process of the ES has been occurring very slowly, especially due to the divergence between what is recommended and what is done in practice:

\footnotetext{
"Now, how I see this process today: still too slow. Slow for several reasons that have delayed this process [...], the teams' own philosophy does not match reality, theory, right? And also, the process itself is something new, right? [...] [Because of] each individual's point of view, and even the way the process was carried out worsened it a little".
}

The comments of two managers deserve attention (Manager B and Manager E) when they talk about carrying out ES by the FHT. Despite the team's apparent agreement on decentralization, the verbal tense in the responses, always referring to the future, allows us to assume the ES actions are not being performed effectively by the HFT. The managers' responses reflect a practice that must be done, but not what is, in fact, being done. Besides, one of the managers' view concerning carrying out ES is reductionist, as it is limited to adopting control and notice measures.

\section{Discussion}

Regarding the planning adopted is observed that is in the opposite direction of decentralization, since thinking in planning with a view to decentralization is thinking within strategic planning and participatory approach. It is understood that a given planning does not apply uniformly to all areas covered (SFH) and the moment in which workers participate in the planning process, increases their responsibility to execute what was planned.

Conceiving planning under a strategic focus implies sharing and distributing power and making sure the social participants engage in the decision making process, which means the municipal district studied advanced in this sense. 
In the interviewees' responses, it is noticed that power of decision is always delegated to other people or other positions. It is like every participant's responsibility was limited to doing what the other determines, without reflecting on the consequences and results from their practices.

Training was considered as an action to solve the problems of workers' practices of those involved in health, when in fact, there are other problems that must be addressed, from professional training at graduation to working conditions offered to these professionals.

It is important to note that from the actors interviewed, particularly the managers emphasized the need for training. Only a professional with university degree referred to training as a strategy used by the central level to decentralize Epidemiologic Surveillance (ES). However, analyzing the tone and how the speech of the professional was expressed one can infer that these skills were not significant for the people who are doing the action, not contributing to the implementation of the decentralization of the ES.

On the other hand, the category of mid-level workers did not mention the training at any time of the interview. This may mean that they participated in educational activities, but do not consider as a convenience to its insertion in ES. or no training focused on this category of workers.

In this direction it is important to mention considerations of Peduzzi and Palma ${ }^{21}$ as the training of mid-level workers processes. For these authors, educational practices are simplified without critical reflection and reaffirm the social inequality of labor.

The municipal district studied does not differ from other districts in Bahia in regards to the way secondary level health workers are trained. The nurse, who integrates the FHT, is usually responsible for training these professionals, in a simplified way, as coincides with the perceptions of Peduzzi and Palma ${ }^{21}$. Not to mention that it is predicted as the nurse's attributions to "develop plans to train the $\mathrm{CHA}$ (Community Health Agent) and nursing assistants, as part of their duties at the health service"18 (p. 34).

The fact that neither the community agent nor the nursing assistant mentioned training in their responses probably indicates that the training they received seems to be naturally integrated in the "normal" practice of detecting communicable disease, and not a specific different training to improve the ES.

It is therefore necessary that the Municipal Health Department reconsiders the professional training processes in a way that corresponds with these workers' needs, resulting in effective actions in practice for the health services.

According to the testimonies, decentralization of ES for the FHT did not overwhelm the health workers, since this activity is not seen as a priority for the team. Actions are developed according to a pre-established program. However, it positively influenced the training for the punctual development of actions. Yet, it may be assumed that the developed training did not assemble elements to contribute to the changes in the workers' practice, as ES is considered, by most participants in this survey, as an action of medical police centered in controlling communicable and temporary diseases as if to identify risks and damages to the population's health.

Concerning organization of work process, it was possible to notice that the way workers for the Family Health Team are hired, notably through temporary contracts, favors professional turnover, impacting negatively not only the development of ES practices, but also other health practices.

The expansion of the health job market occurred in Brazilian cities through the Family Health Program. After the implantation of FHP, there was an important increase of job offers, especially for nurses, nursing technicians and doctors ${ }^{22}$.

Nevertheless, the rise in job offers was inversely proportional to the worker's protection regarding employment contracts, as the municipal districts, justifying the Fiscal Responsibility Law and labor relation flexibility, adopted different contracts, such as cooperatives, temporary contracts and service provision, among others.

It is worth mentioning that not a single worker interviewed cited his precarious insertion in the health system. This may be related to individual interests of each worker in an attempt to save his job. In addition, we may assume that there is lack of political views from workers who end up contributing to this precarious labor relation. 
Noticeably, the responses on work precariousness, and consequently professional turnover, are centered in the group of managers, demonstrating a concern in the rupture of the process of ES decentralization to the FHT. Although the problem of work precariousness had been noticed, especially by the upper managers, no proposal was presented to change this reality. We understand that noticing the problem itself is not sufficient. It is necessary to build possibilities of intervention which assure labor rights stated in the national legislation, avoiding all kinds of work precariousness at UHS.

The results of this study further suggest that there is a predominance of nurses not only as managers, but also as professionals responsible for epidemiological surveillance at the Family Health Unit. Based on Melos'19 ideas, this fact may depict sexism at work, in a way female work has been devalued when compared to males. Also, because it refers to a profession of low economic value and ES is not considered a strategic area for the consolidation of UHS.

Finally, it may be inferred that the Family Health Team's work is limited to controlling communicable diseases, through notification, epidemiological investigation and performing preventive vaccination and vaccination campaigns. Notably, actions are carried out according to the demand of a central sphere from the Municipal Health Office, rather than the necessity perceived by the Professional of the Family Health Unit. As a consequence, they do not observe the population's health condition, let alone their real necessities. As the team does not keep the data produced in the local range, they do not elaborate on information to subsidize the process of making decision.

\section{Final considerations}

Decentralization of ES consists of a process surrounded by contradictions, because at the same time as it is institutionalized, it takes place in incomplete and precarious conditions or due to lack of structure and support from the power supporting foundations or even lack of public participation.

Decentralization brings along a series of responsibilities for the county, without following correspondent financial and management resources for the development of actions. On the other hand, regional differences between state and counties, concerning management and observance of public policies, comprise differentiated ways and levels of decentralization.

We may infer that, in this case, decentralization of ES to the FHT did not actually occur, configuring interruption of activities, as the context determiners analyzed in this study point out the absence of sharing in the decision process. That means it was a hierarchic and normative process.

We understand some issues are crucial so that the decentralization of ES to the SHF in fact may occur, such as: participation of citizens in the health system through municipal and local councils; professional autonomy for performing actions, assessing the obtained results systematically; use of protocols defined by the Health Department and the Municipal Health Department, but with individualized therapeutic projects; development of permanent educational process for the teams, and above all, the local manager's political will. This is a process that involves administrative, technical and political dimensions of municipal UHS organization.

On the other hand, based on Peduzzi and Palma ${ }^{21}$ theoretical concepts, the Family Health Team in the case analyzed performs of varied objects and knowledge not articulated among them; lives with and reproduces various fragmentation plans, either on work organization or on knowledge communication. Confirming what those authors cited, it is necessary to overcome the work logics evidenced in this study so that the Family Health Team is not reduced to a multiprofessional team on a work level. Instead, they may also be considered as an interdisciplinary team in a knowledge level, building new appropriate knowledge to the work needs in health, based on the creation of new practices.

Thus, thinking of the Family Health team logics, is thinking of a multidisciplinary work, sharing the decision process, action planning, horizontal work organization and effective social participation in the management of local health services.

It is understood that the implantation of decentralization of ES to the FHT may represent a way to organize primary health care, as it allows to operate the FHT responsibilities focusing on the individuals 
or groups needs of a specific coverage area. Therefore, it is the FHT's role to develop health promoting actions, disease prevention and care assistance to the individual and the families.

In this regard, the Family Health Unit may help reorganize the health service provision model. However, it is defended that the Family Health Unit will only constitute an effective change strategy if the work process would take local specificities into account and, consequently, the assisted families, building practices that mean improving the population health indicators, the user's satisfaction and the health worker's condition.

This study points to future evaluation research about the implementation of the decentralization of ES to Family Health Teams. It is necessary to develop multiple case studies to obtain a better understanding and theory about this theme. In this way is possible to make some generalizations between similar contexts.

\section{Collaborations}

Silvone Santa Bárbara da S. Santos, Cristina Maria Meira de Melo, Clemence Dallaire e Michel Perreault, participaram igualmente, da elaboração do artigo, de sua discussão e redação e da revisão do texto. Luciano Marques dos Santos, Evanilda Souza de Santana Carvalho, Edna Maria de Araújo participaram da revisão bibliográfica, de discussões e revisão do texto.

\section{Acknowledgments}

The teacher Marcelo Oliveira de Souza for the summary of the review in Portuguese, English and Spanish and the revision of the text in English. To Capes and the Canadian Government, through the Future Leaders Program of America for funding the study in the doctoral period the main author, the Université Laval-Quebec, Canada. 


\section{References}

1. Arretche MTS. Políticas sociais no Brasil: descentralização em um Estado federativo. Rev Bras Cienc Soc. 1999; 14(40):111-32.

2. Dye TR. Understanding public policy. 11a ed. New Jersey: Prentice-Hall; 2005.

3. Guimarães MCL. Descentralização da saúde, interesses e conflitos decisórios: o processo de decisão nas instâncias colegiadas estaduais. Bahia, 1993-1998 [tese]. Salvador (BA): Escola de Administração, Universidade Federal da Bahia; 2000.

4. Lei Orgânica da Saúde n 8080, de 19 de setembro de 1990. Dispõe sobre as condições para promoção, proteção e recuperação da saúde, a organização e o funcionamento dos serviços correspondentes e dá outras providências. Diário Oficial da União. 15 Dez 1990.

5. Baguernand J. Que sais-je? la décentralisation. Paris: Presses Universitaires de France; 2004.

6. Lemieux V. Décentralisation, politiques publiques et relations de pouvoir. Montreal: Les Presses de l'université de Montreal; 2001.

7. Fischer M. Le centralisme et l'aménaement du territoirie en France. In: Ammon G, Hartmeir $M$, organizadores. Federalisme et centralisme: I'avenir de l'Europe entre le modèle allemand et le modèle français. Paris: Economica; 1998. p. 35-46.

8. Dallaire C, organizadora. L'action politique: une stratégie pour l'engagement professionnel. Le savoir infirmier: au coeur de la discipline et de la profession. Montreal: Gaetan Morin Éditeur; 2008.

9. Portaria no 1.399, de 15 de dezembro de 1999. Regulamenta a NOB SUS 01/96 no que se refere ás competências da União, estados, municípios e Distrito Federal, na área de epidemiologia e controle de doenças, define a sistemática de financiamento e dá outras providências. Brasília (DF): Ministério da Saúde; 2000.

10. Santos SSBS, Melo CMM. Avaliação da descentralização da vigilância epidemiológica para a equipe de saúde da família. Rev Bras Cienc Soc. 2008; 6(13):1923-32.

11. Santos SSBS, Melo CMMM, Costa HOG, Tanaka OU, Ramos FM, Santana MCC, et al. Avaliação da capacidade de gestão descentralizada da vigilância epidemiológica no estado da Bahia. Cienc Saude Colet. 2012; 17(4):873-82.

12. Franco TB, Merhy EE. Programa de Saúde da Família (PSF): contradições de um programa destinado à mudança do modelo tecnoassistencial. In: Merhy EE, Magalhães Júnior HM, Rimoli J, Franco TB, Bueno WS, organizaodres. O trabalho em saúde: olhando e experienciando o SUS no cotidiano. 3a ed. São Paulo: Hucitec; 2006. p. 53-124.

13. Watts R. Comparasion des régimes fédéraux des annés. Canadá: University Kingston; 1990.

14. Yin RK. Case study research: design and methods. Thousand Oaks: Sage; 1994.

15. Denis JL, Champagne F. L'analyse d'implantation: modèles et methods. Rev Can D'éval Progr. 1990; 5(2):47-67.

16. Denis JL, Champagne F. Análise de implantação. In: Hartz ZMA, organizadora. Avaliação em saúde: dos modelos conceituais a prática na análise da implantação de programa. Rio de Janeiro: Fiocruz; 2002. p. 49-88.

17. Melo CMM. Inovação e gestão pública em saúde: uma análise da perspectiva local [tese]. São Paulo (SP): Faculdade de Saúde Pública, Universidade de São Paulo; 2001.

18. Bahia. Pólo de capacitação, formação e educação permanente de pessoal para saúde da família - Bahia. Manual para treinamento introdutório das equipes de saúde da família. Salvador: SESAB; 2002.

19. Melo CMM. Divisão social do trabalho e enfermagem. São Paulo: Cortez; 1986. 
20. Gagnon F, Dallaire C. Promotion de La santé: la contribution du savoir infirmier. In: Poulet $O$, Dallaire $C$, organizadores. Les soins infirmiers: vers de nouvelles perspective. Boucherville: Gaetan Morin; 2002. p. 255-76.

21. Peduzzi M, Palma JJL. A equipe de Saúde. In: Schraiber LB, Nemes MIB, MendesGonçalves RB, organizadores. Saúde do adulto: programas e ações na unidade básica. São Paulo: Hucitec; 2000. p. 234-50.

22. Ferreira LMCR. Pesquisa nacional por amostra de domicílio e pesquisa de assistência médico-sanitária: Formação. Merc Trab Saude. 2002; 2(6):93-8.

Santos SSBS, Melo CMM, Dallaire C, Perreault M, Araujo EM, Carvalho ESS, et al. Determinantes contextuales de la descentralización de la Vigilancia Epidemiológica para el Equipo de Salud de la Familia. Interface (Botucatu). 2015; 19(54):443-54.

Este estudio analiza las determinantes contextuales de la implantación de la descentralización de la vigilancia epidemiológica para el Equipo de Salud de la Familia, en un municipio de Bahia, Brasil. Se realizó un estudio de evaluación, adaptándose el modelo político del análisis de implantación. Los datos se obtuvieron por medio del análisis de documentos y entrevistas semi-estructuradas realizadas con gestores y trabajadores de la salud. Surgieron cinco temas: Planificación, capacitación de recursos humanos, organización del proceso de trabajo, articulación intra-institucional, organización de la Unidad de Salud de la Familia. Los resultados muestran dificultades: precaria infraestructura de las unidades de salud, flexibilización de las relaciones de trabajo, rotación de los trabajadores de la salud. El estudio señala la necesidad de participación de los actores en el proceso de implementación de la política de descentralización de la vigilancia epidemiológica para un micro espacio de intervención que es el programa de Salud de la Familia.

Palabras clave: Vigilancia epidemiológica. Descentralización. Determinantes contextuales. Equipo de salud de la familia.

Recebido em 07/10/13. Aprovado em 15/04/15. 